Journal of Sport Coaching and Physical Education 3 (1) (2018)

\title{
PENGARUH POLA LATIHAN LOMPAT KIJANG TERHADAP HASIL LOMPAT JANGKIT MAHASISWA PUTRA PJKR UPGRIS
}

\section{Pandu Kresnapati}

PJKR, FPIPSKR, Universitas PGRI Semarang

\section{Info Artikel}

Sejarah Artikel:

Diterima Juni 2018

Disetujui Juni 2018

Dipublikasikan Agustus

2018

\section{Keywords:}

Lompat Kijang, Lompat

Jangkit

\begin{abstract}
Abstrak
Tujuan dari penelitian ini adalah untuk mengetahui pengaruh latihan lompat kijang terhadap hasil lompat jangkit mahasiswa putra pjkr upgris semester genap tahun pelajaran 2017/2018. Penelitian ini merupakan jenis penelitian eksperimen dengan desain menggunakan one group pretest-posttest design. Instrumen yang digunakan adalah lompat Jangkit dengan subjek dalam penelitian ini merupakan mahasiswa putra pjkr upgris dengan jumlah sebanyak 40 mahasiswa. Teknik pengambilan sampel dengan teknik random sampling. Teknik analisis data yang digunakan dengan menggunakan analisis uji $\mathrm{T}$ Paired Sample t test dengan taraf signifikan $5 \%$. Berdasarkan dari hasil analisis data yang sudah dilakukan dan pembahasan pada uraian yang sebelumnya diperoleh hasil data uji $t$ tersebut dengan nilai thitung $(7,416)>t$ tabel $(2,325)$, dan nilai $p(0,000)$ $<$ dari 0,05, hal tersebut menunjukkan bahwa Ho: "ditolak" dan Ha: "diterima". Dengan demikian dari hasil penelitian ini bisa didapatkan kesimpulan bahwa ada pengaruh yang signifikan pola latihan lompat kijang terhadap hasil lompat jangkit mahasiswa putra PJKR UPGRIS pada semester genap.
\end{abstract}

\section{Abstract}

The purpose of this study was to determine the effect of antelope jumping exercises on the jumping results of the even semester semester of the British college student year 2017/2018. This research is a type of experimental research with a design using one group pretest-posttest design. The instrument used was the Spontaneous Jump with the subjects in this study being 40 male students of the United Kingdom of England. Sampling technique with random sampling techniques. Data analysis techniques used by using the T Paired Sample t test analysis with a significant level of $5 \%$. Based on the results of data analysis that has been done and the discussion in the previous description obtained the results of the $t$ test data with a value of tcount $(7.416)>t$ table $(2,325)$, and $p$ value $(0,000)<0,05$, it shows that Ho: "Rejected" and Ha: "accepted". Thus, from the results of this study, it can be concluded that there is a significant effect of the deer jump training pattern on the results of the inflection of male students of PJKR UPGRIS in the even semester.

C 2018 Universitas Negeri Semarang

\footnotetext{
Alamat korespondensi:

Gedung F1 Lantai 3 FIK UNNES

Kampus Sekaran, Gunungpati, Semarang, 50229

E-mail: jscpe.pklo@unnes.ac.id
} 


\section{PENDAHULUAN}

Olahraga merupakan salah satu bentuk kegiatan fisik dan banyak dilakukan oleh berbagai kalangan masyarakat, dari mulai anak-anak, remaja, dewasa, baik lakilaki maupun perempuan. Salah satu alasan mereka melakukan olahraga adalah mereka mendapatkan kesegaran jasmani dari aktifitas olahraga tersebut yang berpengaruh terhadap kesehatan tubuh sehingga mereka bisa melakukan kegiatan-kegiatan lain dengan lebih baik. Selain itu olahraga juga dimaksudkan untuk pencapaian prestasi bagi mereka yang menggelutinya.

Paradigma pembangunan pendidikan merupakan bagian integral dari pembangunan nasional yang diarahkan menuju kepeningkatan kualitas sumber daya manusia di indonesia seutuhnya. Sebagai bagian dari Pendidikan Nasional, upaya pendidikan jasmani perlu dilaksanakan dengan lebih terencana, teratur serta berkesinambungan. Pelaksanaan pendidikan jasmani dan olahraga merupakan sebuah investasi jangka panjang dalam upaya pembinaan mutu sumber daya manusia terutama di Indonesia saat ini. Pendidikan jasmani dan olahraga di lembaga pendidikan baik di sekolah maupun diperguruan tinggi sebagai salah satu bagian kurikulum pendidikan pelaksanaannya secara berkelanjutan melalui kegiatan pengembangan keterampilan pada unit kegiatan yang ada. Dengan adanya unit kegiatan mahasiswa dikampus diharapkan kemampuan mahasiswa dapat meningkat dengan bentuk-bentuk latihan yang ada khusus yang sesuai dengan cabang olahraga yang diikuti dan diminati. Hal ini penting dilakukan guna pembinaan dan pembibitan olahraga dikalangan mahasiswa meningkat dan dapat mendapatkan hasil yang memuaskan dan yang diinginkan. Latihan secara fisik akan memberikan bekal kemampuan dan keterampilan dalam gerak dasar yang dapat dipergunakan pada latihan dalam perkembangannya untuk mencapai prestasi di bidang olahraga.

Salah satu bagian dari pembelajaran di jurusan olahraga diperguruan tinggi lembaga formal adalah pendidikan gerak dan olah jasmani yang secara khusus merupakan pendekatan ke salah satu cabang olahraga tertentu berdasarkan kurikulum yang berlaku. Diantaranya adalah pembelajaran mengenai cabang olahraga atletik. Atletik merupakan aktivitas jasmani yang efektif untuk mengoptimalkan pertumbuhan dan perkembangan anak. Gerakan-gerakan atletik sangat sesuai untuk mengisi program pendidikan jasmani, seperti lari, lompat, berjalan dan melempar.

Dalam suatu perlombaan atletik terdapat lebih dari satu macam perlombaan. Nomor-nomor dalam atletik yang sering diperlombakan adalah sebagai berikut: (1) nomor jalan dan lari meliputi: jalan cepat, lari jarak pendek (sprint), lari jarak menengah (middle distance), lari jarak jangkit (long distance), dan lari estafet. (2) nomor lompat meliputi: lompat tinggi (hight jump), lompat jangkit (long jump), lompat jangkit (tripple jump), dan lompat tinggi galah (polevoult). (3) nomor lempar meliputi: tolak peluru (shot put), lempar lembing (javelin throw), lempar cakram (discus throw), dan lontar martil (hammer). (Eddy Purnomo dan Dapan, 2011: 1)

Saat proses latihan lompat jangkit, kecepatan mahasiswa saat melakukan lari awalan masih belum maksimal sehingga mengakibatkan hasil 
dari tolakan juga kurang maksimal. Selain itu penyusunan program latihan dan bentukbentuk latihan yang diberikan oleh dosen belum memperhatikan faktor-faktor penentu untuk mencapai hasil lompatan yang optimal, sehingga latihan yang diberikan hanya berupa latihan lompat jangkit secara keseluruhan yang dimulai dari awalan, melayang, menumpu/menolak dan diakhiri mendarat yang dilakukan berulang-ulang tanpa memfokuskan pada peningkatan salah satu aspek penentu hasil lompatan misalnya kecepatan awalan dan langkah kaki.

Dengan hasil observasi yang sudah dilakukan oleh peneliti sebelumnya mengenai kemampuan lompat jangkit mahasiswa putra pjkr upgris semester genap. Bentuk latihan yang diasumsikan baik untuk meningkatkan kemampuan lompat jangkit dengan menggunakan latihan lompat kijang. Bentuk latihan lompat kijang ini diharapkan mampu meningkatkan kemampuan lompat jangkit mahasiswa pjkr upgris menjadi maksimal.

Lompat jangkit sebagai salah satu nomor lompat dari cabang olahraga atletik. Bentuk gerakan lompat jangkit adalah gerakan melompat, mengangkat kaki ke atas dan ke depan dalam upaya membawa titik berat badan selama mungkin di udara (Khomsin, 2008 : 72). Gerakan ini hampir sama dengan lompatan pada nomor lompat jangkit, akan tetapi pada lompat jangkit lebih ditekankan pada saat awalan lari dilanjutkan dengan lompat kijang dengan anggapan akan lebih meringankan dalam gerakan pada saat melompat. Lompat jangkit merupakan gerakan gabungan dari awalan, tolakan, waktu melayang dan mendarat. Gerakan-gerakan tersebut dilakukan secara kontinyu dan antara satu dengan yang lainnya saling menunjang sehingga penguasaan terhadap masingmasing gerakan menjadi sangat penting.

Dalam melakukan suatu latihan harus diketahui faktor-faktor yang mempengaruhi atau memberikan peran bagi tercapainya prestasi yang maksimal dalam cabang olahraga atletik khususnya lompat jangkit. Faktor-faktor yang mempengaruhi terhadap pencapaian hasil lompat jangkit antara lain adalah komponen kondisi fisik yang berupa kecepatan, kekuatan daya ledak dan jenis kelamin.

Latihan merupakan serangkaian peristiwa yang mempengaruhi atlet agar lebih mudah mencapai tujuan, dan merupakan kegiatan yang tertata secara sistematis yang dirancang dan dikembangkan untuk mencapai tujuan belajar. (Herman Subarjah, 2010:138). Latihan adalah suatu proses sistematis dari berlatih atau bekerja yang dilakukan berulang secara kontinyu dengan meningkatkan jumlah beban, untuk tercapainya tujuan latihan (Ida Bagus Wiguna, 2017 : 18).

Latihan yang dimaksud dalam penelitian ini adalah suatu proses yang sistematik dari berlatih atau bekerja yang dilakukan secara berulang-ulang dan kontinyu untuk memperoleh suatu kecakapan melakukan gerakan lompat jangkit. Latihan dilaksanakan oleh mahasiswa bertujuan untuk meningkatkan kekuatan, kecepatan, ketepatan, membentuk daya tahan, dan menambah kelincahan serta keterampilan. Untuk dapat meningkatkan kemampuan secara fisik maupun teknik dilakukan suatu latihan yang didasarkan pada beberapa prinsip latihan. Selain prinsip tersebut yang cukup mendasar untuk program latihan, program latihan dapat diatur dan dikendalikan dengan cara memvariasikan beban latihan seperti 
volume, intensitas, recovery dan frekuensi dalam suatu unit program latihan harian (Tohar, $2004:$ 54).

Lompat Jangkit terbagi dalam beberapa fase: awalan (approach), jingkat (hop), langkah (step), dan lompat (jump) yang terbagi menjadi tolakan (take off) melayang (flight) - pendaratan (landing). (Didik Zafar Sidik, 2014:71).

Dalam fase awalan, pelompat melakukan lari percepatan sampai kecepatan yang terkontrol. Dalam fase jingkat, pelompat melakukan gerakan cepat dan datar, menjangkau $35 \%$ jarak keseluruhan. Dalam fase langkah, pelompat menjangkau kira - kira $30 \%$ jarak keseluruhan. Langkah ini adalah bagian yang paling kritis dalam lompat jangkit. Lama waktunya harus sama dengan tahap jingkat. Dalam fase lompat, pelompat bertolak dengan kaki berlawanan dan menjangkau kira-kira $35 \%$ jarak keseluruhan.

\section{METODE PENELITIAN}

digunakan dalam penelitian ini adalah bentuk One Group Pre-test and Posttest Design, yaitu eksperimen yang dilaksanakan pada satu kelompok saja tanpa adanya kelompok pembanding (Suharsimi Arikunto, 2012: 101). Desain ini dapat digambarkan sebagai berikut dibawah ini:

$$
\mathrm{O} 1 \rightarrow \mathrm{X} \rightarrow \mathrm{O} 2
$$

$\begin{array}{ll}\text { Keterangan : } \\ \text { O1 } \quad \text { : Pretest } \\ \text { O2 } \quad \text { : Postest } \\ \text { X } & \text { : treatment / perlakuan }\end{array}$

Dalam penelitian ini tes dilakukan sebanyak dua kali yaitu sebelum dan sesudah perlakuan (treatment). Perbedaan antara pre-test dan post-test ini diasumsikan merupakan efek dari treatment atau perlakuan. Sehingga hasil dari perlakuan diharapkan dapat diketahui lebih akurat, karena terdapat perbandingan antara keadan sebelum dan sesudah diberi perlakuan. Variabel adalah gejala yang bervariasi yang menjadi objek penelitian (Suharsimi Arikunto, 2012 : 99). Variabel penelitian yang digunakan dalam penelitian ini meliputi :

Latihan lompat kijang, yaitu gerakan yang dilakukan mahasiswa putra pjkr upgris dengan kaki kiri mendorong dan melompatlompat dikuti kedua tangan dilipat di samping badan. Latihan lompat kijang dilakukan sebanyak 18 kali.

Hasil dari lompat jangkit, yaitu kemampuan mahasiswa putra pjkr upgris dalam melakukan lompatan jangkit secara maksimal pada bak lompat dan diukur jaraknya dengan satuan meter.

Untuk memperoleh data yang sesuai, penulis menggunakan instrumen tes. Tujuan dari tes ini adalah untuk mengukur pola kemampuan mahasiswa putra pjkr upgris dalam melakukan lompat jangkit. Instrumen tes yang digunakan dalam penelitian ini adalah tes lompat jangkit dengan tujuan mengukur pola kemampuan mahasiswa dalam melakukan lompat jangkit. Pelaksanaan tes dengan mengambil awalan lari, kemudian mahasiswa melakukan gerakan lari secepat-cepatnya dan melakukan teknik lompatan kijang sampai ke papan tolakan yang pertama dan dilanjutkan kemudian melakukan tolakan kembali sampai pada balok yang ke dua dan diakhiri dengan melompat ke bak pasir 
untuk mencapai jarak lompatan sejauh mungkin.

\section{HASIL DAN PEMBAHASAN}

Penelitian ini dimaksudkan untuk mengetahui pengaruh pola latihan lompat kijang terhadap hasil lompat mahasiswa putra pjkr upgris.

\section{Distribusi Data Pre-test Lompat Jangkit Mahasiswa Pjkr Putra Upgris}

Hasil dari penelitian pola latihan lompat jangkit mahasiswa putra pjkr upgris saat dilakukan pengambilan data awal pretest, diperoleh Nilai minimum $=1,21$, nilai maksimum $=1,47$, rerata $=1,29 ;$ median $=$ 1,$29 ;$ modus $=1,20$ dan standard devias $i=$ 0,14 . Hasil tersebut dapat dilihat pada tabel yang tertera di bawah ini:

Tabel 1. Distribusi Frekuensi Lompat Jangkit Pre-test

\begin{tabular}{|c|c|c|}
\hline Nilai & Frekuensi & Persentase \\
\hline $1,21-1,28$ & 4 & 12,8 \\
\hline $1,29-1,36$ & 13 & 33,1 \\
\hline $1,37-1,44$ & 9 & 18,1 \\
\hline $1,45-1,52$ & 9 & 23,6 \\
\hline $1,53-1,60$ & 5 & 12.4 \\
\hline Jumlah & 40 & 100 \\
\hline
\end{tabular}

Distribusi Data Post-test Lompat Jangkit Mahasiswa Pjkr Putra Upgris

Hasil penelitian pola latihan lompat jangkit mahasiswa putra pjkr upgris saat post-test, diperoleh nilai minimum $=1,27$, nilai maksimum $=1,53$, rerata $=1,47$; median $=1,52 ;$ modus $=1,43$ dan standard deviasi $=0,108$. Hasil tersebut dapat dilihat pada tabel di bawah ini:
Tabel 2. Distribusi Frekuensi Lompat Jangkit Post-test

\begin{tabular}{|c|c|c|}
\hline Nilai & Frekuensi & Persentase \\
\hline $1,27-1,32$ & 3 & 12,3 \\
\hline $1,33-1,39$ & 8 & 26,1 \\
\hline $1,40-1,47$ & 13 & 25,7 \\
\hline $1,48-1,55$ & 7 & 18,2 \\
\hline $1,56-1,62$ & 9 & 17,7 \\
\hline Jumlah & 40 & 100 \\
\hline
\end{tabular}

Persentase Peningkatan

Untuk mengetahui besarnya pengaruh pola latihan lompat kijang terhadap hasil lompat jangkit mahasiswa putra pjkr upgris dalam penelitian ini menggunakan besarnya persentase peningkatan yang diperoleh. Hasil pre-test diperoleh 1,29, Sedangkan pada hasil posttest diperoleh sebesar 1,47. Dengan hasil tersebut maka peningkatan persentasenya dapat dihitung sebagai berikut

Hasil peningkatan persentasenya sebesar 4,17\%, dengan ada peningkatan tersebut maka dapat diartikan latihan lompat kijang memberi pengaruh positif dan meningkat terhadap hasil lompat jangkit mahasiswa putra pjkr upgris.

\section{Uji Hipotesis (Uji-T)}

Pengujian hipotesis dilakukan untuk mengetahui penerimaan atau penolakan hipotesis yang diajukan, uji hipotesis menggunakan uji-t pada taraf signifikan $5 \%$. Hasil uji hipotesis (uji-T) dapat dilihat pada tabel di bawah ini: 
Tabel 3. Hasil Uji Hipotesis (Uji T)

\begin{tabular}{|c|c|c|c|c|c|}
\hline Pre-post & Df & T tabel & $\begin{array}{c}\mathrm{T} \\
\text { hitung }\end{array}$ & $\mathbf{P}$ & $\begin{array}{l}\text { Sig } \\
5 \%\end{array}$ \\
\hline $\begin{array}{l}\text { Lompat } \\
\text { Jangkit }\end{array}$ & 40 & 2,325 & 7,416 & 0,000 & 0,05 \\
\hline
\end{tabular}

Berdasarkan hasil uji $t$ tersebut diperoleh nilai $\mathrm{t}_{\text {hitung }}(7,416)>\mathrm{t}$ tabel $(2,325)$, dan nilai $p(0,000)<$ dari 0,05 , hal tersebut menunjukkan diartikan Ho: Ditolak dan Ha: Diterima. Jika Ha diterima maka hipotesisnya "ada pengaruh pola latihan lompat kijang terhadap hasil lompat jangkit mahasiswa putra pjkr upgris semester genap tahun pelajaran 2017/2018".

Latihan lompat kijang yang dilakukan oleh mahasiswa merupakan latihan yang berfungsi untuk meningkatkan fungsi kekuatan otot kaki pada bagian tubuh, dengan meningkatnya kekuatan otot kaki maka secara tidak langsung power daya ledak kekuatan pada kaki dapat menjadi meningkat pada mahasiswa yang melakukan lompat jangkit lebih jauh lagi. Dengan demikian dapat diartikan bahwa latihan lompat kijang memberi efek terhadap kemampuan mahasiswa dalam melakukan lompat jangkit.

\section{SIMPULAN}

Berdasarkan dari hasil analisis data dan pembahasan pada uraian pada sebelumnya telah diperoleh hasil uji $\mathrm{t}$ tersebut diperoleh nilai thitung $(7,416)>\mathrm{t}$ tabel $(2,325)$, dan nilai $p(0,000)<$ dari 0,05 , hal tersebut menunjukkan diartikan Ho: ditolak dan Ha: diterima. Dengan demikian didapatkan hasil dari penelitan ini dengan adanya pengaruh pola latihan lompat kijang terhadap hasil lompat jangkit mahasiswa putra pjkr upgris semester genap tahun pelajaran 2017/2018.

\section{DAFTAR PUSTAKA}

Didik Zafar Sidik, 2017. Mengajar dan Melatih Atletik. Bandung : PT Remaja Rosdakarya

Eddy Purnomo dan Dapan. 2011. Dasar dasar Gerak Atletik. Yogyakarta: Alfamedia.

Herman Subarjah. Pengaruh Model Latihan Terhadap Hasil Belajar Keterampilan. Jurnal IPTEK Olahraga.Kementerian Pemuda dan Olahraga RI. Vol 12, No 2, MeiAgustus 2010. ISSN: 14411-0016.

Ida Bagus Wiguna. 2017. Teori dan Aplikasi Latihan Kondisi Fisik. Depok: PT. Raja Grafindo Persada.

Khomsin. 2008 . Dasar - dasar Pembelajaran Lompat Jangkit, Lari Gawang, Lempar Lembing. UNNES PRESS.

Suharsimi Arikunto. 2012. Prosedur Penelitian Suatu Pendekatan Praktek. Jakarta : Rineka Cipta

Tohar, 2004. Ilmu Kepelatihan Lanjut. Semarang : FIK UNNES 